\title{
ANALISA PEMBIAYAAN MANUFAKTUR PADA BANK PEMBIAYAAN RAKYAT SYARIAH
}

\author{
Alvira 'Aina A'yun \\ Universitas Airlangga, Indonesia
}

$\triangle$ Corresponding Author:

Nama Penulis: Alvira 'Aina A'yun

E-mail: alvira.aina.ayun-2018@pasca.unair.ac.id

\section{Abstract}

Real sector is one of sectors that support economic improvement. Islamic rural banks provide service in manufacture industry in their operational. The combination of Islamic rural banks and manufacture sector expected to doing well and contribute in economic growth. Purpose of this study to examine effect of financing in Islamic rural bank toward real sektor. The research aim to identify connection between financial performances, financing akad, third party fund, inflation, exchange rate with financing in Islamic Rural Bank in real sector. This study uses quantitative field research. Further, the source is secondary data from Islamic Rural Bank report in Financial Services Authority, Indonesian Central Bank and Ministry of Commerce. These sources of data are used to examine Real sector financing from January 2014 until December 2018. The techniques of data collection was multiple regression analysis using Eviews version 7. These method were used for analysing the effect of financing performance, akad in financing, third party fund, inflation and exchange rate toward financing in real sector. Financing performance, third party fun, akad in financing, inflation and exchange rate have effect on financing in manufacture sector in Islamic rural banks. This study recommendation for Islamic Rural banks in upgrade banking activity, give knowledge to government to give rights policy for Islamic rural banks to operate the banking activity.

Key words: BPRS; Financial Performance; Financing Akad

\section{Abstrak}

Sektor perekonomian riil merupakan salah satu sektor yang mendukung peningkatan ekonomi. BPRS menyediakan layanan bagi industri manufaktur dalam menjalankan operasionalnya. Kombinasi BPRS dan sektor manufaktur diharapkan dapat berjalan dengan baik dan berkontribusi pada pertumbuhan ekonomi. Tujuan dari penelitian ini untuk meneliti efek yang mempengaruhi pembiayaan yang dilakukan oleh BPRS pada bidang sektor riil di Negara Indonesia, dan untuk mengetahui keterkaitan antara kinerja keuangan, akad pembiayaan, dana pihak ketiga, inflasi dan nilai tukar. Metodologi dari penelitian ini adalah kuantitatif. Data diambil dari laporan keuangan BPRS yang ada di OJK, data inflasi di ambil dari Bank Indonesia, nilai tukar diambil dari data kementerian perdagangan. Data yang digunakan adalah data BPRS, 
kinerja keuangan, dana pihak ketiga, akad pembiayaan, inflasi dan nilai tukar pada Januari 2014 sampai Desember 2018. Hasil uji regresi berganda menunjukkan hasil bahwa adanya pengaruh secara simultan antara variabel kinerja keuangan, dana pihak ketiga, akad pembiayaan, inflasi dan nilai tukar terhadap sektor riil dalam hal ini manufaktur. Adanya penelitian ini dapat memberikan informasi kepada BPRS untuk meningkatkan aktivitas perbankan serta kepada pemerintah untuk memberikan kebijakan yang tepat atas kegiatan operasional BPRS. Kebaruan pada penelitian ini adalah menggunakan variabel BPRS sebagai variabel lembaga keuangan dan pembiayaan yang dilakukan pada sektor riil.

Kata kunci: BPRS; Kinerja Keuangan; Akad Pembiayaan

\section{PENDAHULUAN}

Manufaktur merupakan salah satu sektor ekonomi yang didanai oleh Bank Pembiayaan Rakyat Syariah (BPRS). Industri manufaktur sendiri memberikan sumbangan hampir seperempat produk domestik bruto di Indonesia. Mengandalkan sektor riil maka ekonomi negara akan terus berjalan meski sedang mengalami krisis. Manufaktur terbesar di Indonesia berupa industri makanan dan minuman. Beberapa tahun terakhir, terdapat kenaikan pada sektor manufaktur seperti industri kimia dan alat transportasi, sumbangan sektor tekstil, pakaian jadi, dan produk jadi memiliki andil dalam penyerapan tenaga kerja dan produksi. Pada triwulan ketiga tahun 2018 industri pengolahan baik migas maupun non migas mengalami peningkatan sebesar 4.24\% lebih tinggi dibandingkan tahun 2017 yang hanya sebesar 4.21\%. Industri manufaktur sendiri memiliki dampak pada perekonomian Indonesia serta memiliki potensi yang lebih baik lagi untuk dikembangkan agar dapat membantu menopang perekonomian Indonesia. Salah satu upaya yang dilakukan untuk melakukan kegiatan produksi adalah kepemilikan modal yang salah satunya didukung oleh pembiayaan pada sektor ekonomi pada BPRS (Kompas, 2016).

Pertumbuhan produksi industri manufaktur pada triwulan III-2018 berdasarkan data BPS industri besar sedang menempati $5.04 \%$ yoy terdiri atas industri pakaian jadi mengalami kenaikan sebesar $23.13 \%$, sejalan dengan industri karet, barang dari karet dan plastik sebesar 18.84\% serta adanya penurunan pada industri komputer, barang elektronik dan plastik sebesar 22.31\%. Pada industri mikro, kecil produksi yang dilakukan sebesar $3.88 \%$ yoy dengan rincian adanya kenaikan pada industri logam dasar sebesar $18.64 \%$ serta industri percetakan dan reproduksi media rekaman sebesar $17.72 \%$ namun terjadi penurunan pada industri pengolahan tembakau sebesar 44.78\%. Menurut data BPS pertumbuhan industri manufaktur besar dan sedang triwulan-I 2019 naik sebesar 4.45 persen yoy terhadap triwulan I-2018. Adanya kenaikan disebabkan oleh produksi 
industri pakaian jadi naik sebesar 29.19 persen sedangkan pada industri jasa reparasi dan pemasangan mesin turun sebesar 20,98\%(Badan Pusat Statistik, 2019).

Perbankan merupakan salah satu lembaga yang berfungsi melayani masyarakat dalam hal keuangan. Perbankan memainkan peran sebagai lembaga intermediate yang menangani keuangan mulai dari masyarakat hingga perusahan, dari lembaga keuangan mikro hingga makro membutuhkan peran perbankan. Perbankan yang khusus melayani lingkup mikro salah satunya adalah Bank Perkreditan Rakyat dan Bank Pembiayaan Rakyat Syariah. Pada penelitian ini akan lebih menekankan pada Bank Pembiayaan Rakyat Syariah (BPRS) dimana tujuan dari pendirian bank ini adalah memberikan fasilitas pada pengusaha kecil dan pinggiran kota yang umumnya kurang bisa dijangkau oleh bank umum baik konvensional maupun syariah.

Penelitian yang dilakukan oleh (Hosen \& Muhari, 2019) Umumnya BPRS memiliki tujuan dan karakteristik yang sama dengan beberapa institusi mikro lainnya. BPRS memiliki 2 objek utama yang dapat dicapai sekaligus yaitu pengembangan komersial dan komunitas. BPRS dalam operasionalnya tidak hanya menjadi profit namun juga untuk melayani komunitas. BPRS di Indonesia sebanyak 164 yang tersebar di seluruh Indonesia. Indonesia merupakan Negara yang memiliki perbedaan microfinance baik dalam konvensional dan Islam. Keuangan Islam mulai berkembang sekitar tahun 1990 diikuti BPRS pada tahun 1991 dan bank umum syariah pada tahun 1992(Fithria \& Sholihin, 2018).

Adanya BPRS berdasarkan Undang-Undang No. 7 Tahun 1992 mengenai Bank berdasarkan prinsip bagi hasil. Selanjutnya pengaturan mengenai BPRS diubah menjadi Undang-Undang No. 10 Tahun 1998. Perbankan sebagai perantara keuangan memiliki peran penting dalam alokasi simpanan ke proyek paling produktif. Untuk mengalokasikan dana kepada proyek dibutuhkan penilaian pada resiko, penggunaan dana dan memastikan penggunaan modal paling efisien (Yusof, Rosylin Mohd; Bahlous, 2013). Bank pembiayaan rakyat syariah sendiri kegiatan usahanya hanya berfokus pada pembiayaan. Banyak sektor yang dibiayai oleh BPRS salah satunya mengenai industri atau manufaktur. Industri manufaktur merupakan industri yang berkaitan dengan menghasilkan suatu barang jadi agar dapat dimanfaatkan.

Penelitian yang dilakukan oleh (Abas, 2017) mengenai peran bank syariah dalam penguatan UMKM di Maluku selatan, dalam penelitian ini menghasilkan peran lembaga keuangan perbankan sebagai lembaga penunjang dalam jalannya UMKM sebagai pilar dalam perekonomian. Selanjutnya penelitian yang dilakukan oleh (Suhel et al., 2018) mengenai 
pengaruh pembiayaan UMKM dan skala perhitungan ekonomi pada industri bank syariah. Hasil menunjukkan dana pihak ketiga, pekerja, non-performing finances, kantor cabang UMKM memiliki pengaruh secara signifikan pada pembiayaan UMM ketika jumlah kantor cabang pada perbankan tidak memiliki pengaruh pada pembiayaan UMKM.

Penelitian ini merupakan pengembangan dari penelitian yang dilakukan oleh (Kusmayadi, 2018) yaitu meneliti mengenai efek dari CAR, LR, NPL, BOPO terhadap tingkat pengembalian aset pada BPR di Indonesia dimana CAR cenderung memiliki predikat sehat lebih tinggi, LDR berada dalam kategori sehat, NPL masih dalam predikat namun memiliki tren yang menurun, BOPO masih diawasi dan termasuk dalam kategori sehat. Secara parsial, CAR dan NPL memiliki hasil negatif tidak signifikan, LDR memiliki efek positif namun tidak signifikan senakan BOPO dan ukuran BPRS memiliki efek signifikan negatif pada ROA. Secara simultan CAR, LDR, NPL, BOPO dan ukuran memiliki efek signifikan pada pengembalian aset. Pada penelitian ini penulis menggunakan Kinerja Keuangan, Akad Pembiayaan, Dana Pihak Ketiga, Inflasi, Nilai Tukar pada pembiayaan yang dilakukan BPRS terhadap industri manufaktur. Sehingga tujuan dari penelitian ini yaitu untuk mengetahui bagaimana pengaruh pembiayaan yang dilakukan oleh BPRS pada salah satu sektor ekonomi yaitu pada bidang industri.

\section{KAJIAN PUSTAKA}

Praktik keuangan mikro syariah di Indonesia merupakan bagian yang tak terpisahkan dalam gerakan keuangan mikro. Mayoritas gerakan keuangan mikro ini lebih bersifat bottom up dimana gerakan ini diawali oleh masyarakat atau komunitas membutuhkan pelayanan keuangan atau kemudahan untuk mendapatkan modal usaha. Terdapat lembaga khusus yang menjalankan kegiatan operasional sebagai institusi keuangan mikro yaitu institusi keuangan mikro yang berdiri atas inisiatif non pemerintah yaitu BPRS. Berdasarkan data Otoritas Jasa Keuangan pada bulan Juni 2019 terdapat 164 BPR Syariah angka ini lebih rendah dari angka jumlah tahun sebelumnya yakni sebesar 168 (OJK, 2019). Hal ini dapat disebabkan karena kurangnya data keuangan mikro syariah baik yang berbadan hukum maupun belum.

Terdapat Undang-Undang No. 7 Tahun 1992 mengenai perbankan dimana BPR adalah lembaga keuangan bank yang menerima simpanan hanya dalam bentuk deposito berjangka atau setara dengan itu. Pada Undang-Undang Perbankan No. 10 Tahun 1998 dijelaskan bahwa BPR merupakan lembaga keuangan bank yang melaksanakan usahanya baik secara konvensional maupun syariah. Menurut Undang-Undang No. 21 Tahun 2008 mengenai perbankan syariah, BPRS merupakan bank syariah yang dalam kegiatannya tidak memberikan jasa dalam lalu lintas pembayaran (Al Arif, 2012). 
Tujuan BPRS adalah meningkatkan kesejahteraan ekonomi terutama yang berada di desa, meningkatkan lapangan kerja, membina semangat ukhuwah Islamiyah, mempercepat perputaran aktivitas ekonomi karena memberdayakan sektor riil. Menurut UU No. 21 Tahun 2008 BPRS memiliki kegiatan usaha meliputi penghimpunan dan penyaluran dana, menempatkan dana pada bank syariah lain dapat berupa titipan maupun investasi, memindahkan uang, menyediakan produk atau melakukan kegiatan usaha yang sesuai prinsip syariah (Al Arif, 2012).

Penelitian yang dilakukan oleh (Viverita et al., 2015) menganalisa mengenai hubungan antara kepemilikan perbankan oleh asing dan alokasi pinjaman bank untuk usaha mikro. Hasil penelitian tidak ada peraturan khusus untuk mengatur kebutuhan usaha mikro, bank asing hanya membiayai perusahan besar yang memberikan keuntungan. Non-Performing Loan Syariah memiliki dampak yang positif pada perilaku pinjaman bank terhadap UKM. Ketika bank memiliki kecukupan modal maka mereka lebih banyak memberikan pinjaman pada usaha mikro. Penelitian selanjutnya dilakukan oleh (Diallo, 2018) yang meneliti keterkaitan antara efisiensi bank dan pinjaman bank terhadap industri. Peneliti menggunakan data dari 36 industri pada 38 negara di dunia. Hasil dari penelitian menunjukkan bahwa efisiensi bank memiliki dampak yang positif terhadap penawaran dari kredit perusahaan dimana dapat menambah tingkat pertumbuhan pada industri dan yang paling banyak berpengaruh adalah pembiayaan eksternal.

Manufaktur merupakan salah satu sektor ekonomi yang diberikan pembiayaan oleh BPRS. Penelitian mengenai manufaktur atau sektor ekonomi riil diperkuat oleh penelitian yang dilakukan oleh (Rafay \& Farid, 2017) mengenai hubungan dinamis antara perbankan syariah dengan sektor ekonomi riil dimana pada penelitian yang dilakukan menggunakan sektor manufaktur pada Negara Pakistan.

Kinerja keuangan pada penelitian ini menggunakan variabel CAR atau rasio kecukupan modal, ROA dan ROE atau rasio pengembalian asset, NPF atau rasio kemampuan bank untuk membayar atas pembiayaan bermasalah, BOPO merupakan biaya operasional yang dikeluarkan atas pembiayaan yang dilakukan. Penggunaan variabel ini juga digunakan oleh (Muhaemin \& WIliasih, 2016) dimana penelitian yang dilakukan muhaemin dan wiliasih menggunakan variabel CAR dan FDR memiliki pengaruh positif signifikan terhadap profitabilitas, NPF, BOPO memiliki pengaruh yang signifikan namun negative terhadap profitabilitas dalam BPRS sedangkan BI rate tidak berpengaruh secara signifikan dalam penelitian yang dilakukan.

Dana merupakan hal yang penting dalam perbankan dimana dana ini biasanya berasal dari masyarakat dapat berupa giro iB- akad wadiah, Tabungan iB menggunakan akad wadiah dan mudharabah, deposito iB menggunakan akad mudharabah. Penggunaan DPK dalam penelitian didukung oleh penelitian yang 
dilakukan (Wiyono \& Mulatsih, 2017) dimana mereka meneliti mengenai analisis faktor eksternal dan performance indikator BPRS Indonesia terhadap pembiayaan sektor perdagangan hotel dan restoran. Variabel yang digunakan adalah BI rate, inflasi, PaR dan DPK menghasilkan hubungan yang tidak signifikan dengan menggunakan uji VECM.

Akad yang digunakan dalam pembiayaan pada BPRS adalah akad mudharabah, akad musyarakah, akad murabahah, akad salam, akad istishna, akad ijarah dan akad qard. Penggunaan akad yang berbeda menandakan perbedaan penggunaan pembiayaan pada sektor ekonomi yang dibiayai oleh BPRS. Data OJK pada statistik perbankan syariah dapat dilihat bahwa dana yang ada di BPRS banyak disalurkan menggunakan akad murabahah. Penelitian yang dilakukan oleh (Agza \& Darwanto, 2017) mengenai akad pembiayaan digunakan dalam meneliti mengenai profitabilitas pada BPRS yang ditinjau dari akad pembayaran yakni murabahah dan musyarakah menghasilkan pengaruh yang signifikan pada profitabilitas BPRS.

Inflasi adalah kenaikan harga barang dalam waktu tertentu. Inflasi merupakan masalah yang pasti dihadapi oleh suatu Negara. Inflasi digunakan untuk mengetahui seberapa buruknya masalah ekonomi suatu Negara. Dalam penelitian ini menggunakan variabel inflasi sebagai variabel makroekonomi. Variabel inflasi digunakan dalam penelitian perbankan diperkuat oleh penelitian dari (Rahmat Dahlan, 2014) mengenai pengaruh tingkat bonus Sertifikat Bank Indonesia Syariah (SBIS) dan inflasi terhadap pembiayaan pada bank Syariah di Indonesia dan menghasilkan adanya efek yang negatif terhadap bonus SBIS pada pembiayaan bank di Indonesia serta inflasi tidak memiliki pengaruh pada pembiayaan bank syariah di Indonesia.

Nilai tukar rupiah terhadap Dolar menjadi salah satu variabel dalam pembiayaan yang dilakukan pada sektor manufaktur pada BPRS. Penggunaan nilai tukar sebagai variabel yang mempengaruhi pembiayaan juga diteliti oleh (Masudah, 2017). Penelitian yang dilakukan oleh (Rafay \& Farid, 2017) mengenai hubungan dinamis antara bank Islam dan aktivitas ekonomi riil yang mengambil studi kasus di Pakistan menggunakan variabel deposito, pembiayaan dan investasi pada bank syariah dan indeks skala manufaktur sebagai variabel dari aktivitas sektor ekonomi riil. Hasil penelitian ini mengemukakan adanya hubungan yang signifikan dan positif dan dinamis pada jangka panjang antara perbankan syariah dan sektor ekonomi riil. Penelitian yang dilakukan oleh (Rafay \& Farid, 2017) ini merupakan titik awal ide penulis dalam menulis mengenai hubungan antara perbankan dan sektor ekonomi riil. Dengan menggunakan variabel lain yakni menggunakan Bank Pembiayaan Rakyat Syariah terhadap sektor ekonomi riil.

\section{HIPOTESIS}

Hipotesis yang digunakan pada penelitian ini adalah sebagai berikut: 
H1: CAR memiliki pengaruh signifikan pada pembiayaan manufaktur pada BPRS di Indonesia

H2: ROA memiliki pengaruh signifikan pada pembiayaan manufaktur pada BPRS di Indonesia

H3: ROE memiliki pengaruh signifikan pada pembiayaan manufaktur pada BPRS di Indonesia

H4: NPF memiliki pengaruh signifikan pada pembiayaan manufaktur pada BPRS di Indonesia

H5: BOPO memiliki pengaruh signifikan pada pembiayaan manufaktur pada BPRS di Indonesia

H6: DPK memiliki pengaruh signifikan pada pembiayaan manufaktur pada BPRS di Indonesia

H7: Akad pembiayaan memiliki pengaruh signifikan pada pembiayaan manufaktur pada BPRS di Indonesia

H8: Inflasi memiliki pengaruh signifikan pada pembiayaan manufaktur pada BPRS di Indonesia

H9: Nilai tukar memiliki pengaruh signifikan pada pembiayaan manufaktur pada BPRS di Indonesia

H10: CAR, ROA, ROE, NPF, BOPO, DPK, Akad Pembiayaan dan Nilai tukar memiliki pengaruh signifikan pada pembiayaan manufaktur pada BPRS di Indonesia

\section{METODE}

Penelitian ini dilakukan pada Bank Pembiayaan Rakyat Syariah dimulai pada Januari 2014 hingga Desember 2018. Data yang digunakan adalah data sekunder dari BPRS yang didapatkan dari publikasi perbankan pada website Otoritas Jasa Keuangan dan Bank Indonesia. Jenis data dalam penelitian ini adalah data time series. Metode analisa yang digunakan adalah regresi linier berganda (multiple regression analysis model) dengan persamaan kuadrat terkecil (Ordinary Least Square) dimana metode ini dapat memprediksi masa depan. Penelitian ini menggunakan alat hitung Eviews 9.

Estimasi persamaan OLS dalam penelitian ini dirumuskan sebagai berikut

$Y=\alpha+\beta_{1} X_{1}+\beta_{2} X_{2}+\beta_{3} X_{3}+\beta_{4} X_{4}+\beta_{5} X 5+\beta_{6} X_{6}+\beta_{7} X_{7}+\beta_{8} X_{8}+\beta_{9} X_{9}+\varepsilon$

Dimana :

$\mathrm{Y}=\quad$ Manufaktur

$\alpha=$ Konstanta

$\mathrm{X} 1=$ Capital Adequacy Ratio

$\mathrm{X} 2=$ Return on Asset

$\mathrm{X} 3=$ Return On Equity

$\mathrm{X} 4=$ Non Performing Finance 
X5 = Biaya Operasional Pendapatan Operasional

$\mathrm{X} 6=$ Dana Pihak Ketiga

$\mathrm{X} 7=$ Akad Pembiayaan

$\mathrm{X} 8=$ Inflasi

$\mathrm{X} 9=$ Kurs Rupiah-Dolar

$\beta_{1}, \beta_{2}, \beta_{3}, \beta_{4}, \beta_{5}, \beta_{6}, \beta_{7}, \beta_{8}, \beta_{9=}$ koefisien regresi

$\varepsilon=\quad$ Standard error

Data yang digunakan dalam penelitian ini adalah manufaktur sebagai variabel dependen, rasio kecukupan modal (CAR), rasio pembiayaan bermasalah pada perbankan (NPF), rasio kemampuan bank dalam mendapatkan laba (ROA), rasio kemampuan dalam mendapatkan laba pada dana yang diinvestasikan (ROE), rasio efisiensi bank dalam melakukan kegiatan operasionalnya (BOPO), Dana Pihak Ketiga, Akad Pembiayaan, Inflasi dan Kurs Rupiah-Dolar.

Pembiayaan merupakan akad yang digunakan untuk melakukan transaksi keuangan. Pengambilan data dari statistik laporan perbankan syariah di Indonesia. Pengambilan data manufaktur sebagai variabel yang diteliti dikarenakan industri manufaktur merupakan industri yang berkaitan dengan sektor ekonomi riil.

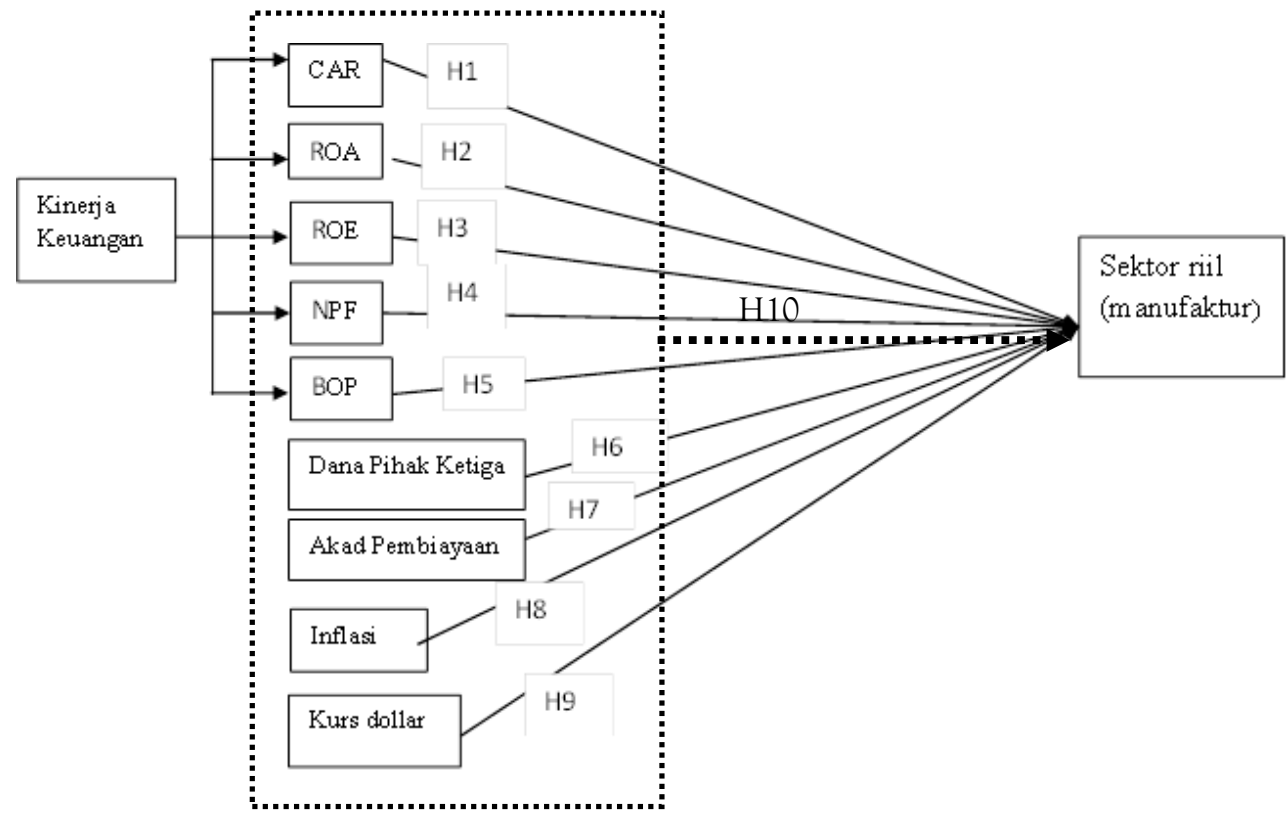

Gambar 1. Model Penelitian

Sumber : penulis, 2019

Pengambilan kinerja keuangan seperti CAR, NPF, ROA, ROE, BOPO sebagai faktor yang mungkin mempengaruhi pembiayaan yang dilakukan BPRS kepada sektor industri dan diambil dari statistik laporan keuangan 
perbankan syariah di Indonesia. Pemilihan DPK, akad yang digunakan sebagai pembiayaan sebagai faktor yang mendukung dalam pembiayaan industri manufaktur sedangkan untuk variabel makroekonomi terdapat inflasi serta nilai tukar rupiah terhadap dollar. Untuk data DPK serta macam akad pembiayaan yang digunakan diambil dari statistik laporan keuangan perbankan syariah, sedangkan untuk inflasi dan kurs diambil dari website Bank Indonesia.

\section{HASIL DAN PEMBAHASAN}

Pada bagian ini akan dipaparkan hasil dari penelitian yang dilakukan yaitu antara manufaktur dan kinerja keuangan, DPK, pembiayaan serta kurs dan inflasi. Perhitungan menggunakan Eviews 9. Penelitian menggunakan uji regresisi berganda atau OLS dengan data yang digunakan time series. Sebelum melakukan uji secara simultan, dibutuhkan uji asumsi klasik untuk menguji setiap variabel dan permasalahan dalam setiap variabel yang digunakan.

Tabel 1. Hasil Pengujian Hipotesis

\begin{tabular}{lrrr}
\hline \multicolumn{1}{c}{ Variabel } & Coefficient & t & \multicolumn{1}{c}{ Prob } \\
\hline C & -141.2114 & -2.298207 & 0.0271 \\
\hline CAR & 0.398963 & 0.489165 & 0.6275 \\
\hline ROA & -15.78841 & -1.287519 & 0.2057 \\
\hline ROE & 0.103210 & 0.079924 & 0.9367 \\
\hline NPF & -0.589680 & -0.576086 & 0.5680 \\
\hline BOPO & 0.601938 & 1.098291 & 0.2790 \\
\hline DPK & $9.32 \mathrm{E}-06$ & 2.339044 & 0.0247 \\
\hline Akad Pembiayaan & $9.48 \mathrm{E}-06$ & 2.230165 & 0.0317 \\
\hline Inflasi & 5.498991 & 7.076946 & 0.0000 \\
\hline Nilai Tukar & 3.380705 & 2.210530 & 0.0332 \\
\hline Sur
\end{tabular}

Sumber : Data diolah, 2019

Pada Tabel 1 memaparkan empat variabel yang signifikan pada tingkat signifikansi 0.05 yaitu variabel DPK, Akad Pembiayaan, Inflasi dan Nilai Tukar (kurs). Sedangkan variabel CAR, ROA,ROE, NPF, BOPO tidak memiliki pengaruh yang signifikan terhadap pembiayaan yang dilakukan BPRS kepada sektor ekonomi riil yaitu manufaktur.

Tabel 2. Hasil Uji Kelayakan Model

\begin{tabular}{ccccc}
\hline $\begin{array}{c}\text { Sum of } \\
\text { Squares }\end{array}$ & R-squared & $\begin{array}{c}\text { Adjusted R- } \\
\text { Squared }\end{array}$ & F & Prob \\
\hline 526.0143 & 0.966335 & 0.958362 & 121.1962 & 0.000000 \\
\hline
\end{tabular}

Sumber : Data diolah, 2019

Pada Tabel 2 dikeyahui hasil uji F atau uji secara simultan dimana nilai F sebesar 121.1962 dengan tingkat prob 0.00000 sehingga dapat dikatakan 
bahwa variabel kinerja keuangan, DPK, akad pembiayaan, inflasi, kurs secara bersama-sama atau simultan memiliki pengaruh positif. Dalam Tabel. 2 juga menunjukkan nilai R-squared atau koefisien determinasi sebesar 0.958 atau 95.8\% hal ini berarti variabel yang digunakan dalam penelitian ini mewakili 95.8\% terhadap pembiayaan manufaktur di BPRS dan sebanyak 4.2\% diwakili oleh variabel lain yang tidak diteliti.

\section{Pengaruh CAR terhadap pembiayaan sektor manufaktur}

Pada Tabel 1. menunjukkan hasil perhitungan dari CAR atau rasio kecukupan modal dalam penelitian ini memiliki hubungan yang tidak signifikan. Dimana nilai CAR menunjukkan 0.627 melebihi tingkat signifikansi sebesar 0.05. Tidak adanya pengaruh CAR terhadap pembiayaan sejalan dengan penelitian yang dilakukan (Permatasari, Devi; Yulianto, 2018) dimana CAR tidak signifikan terhadap penyaluran pembiayaan pada perbankan syariah. Hal ini dikarenakan BPRS merupakan lembaga keuangan yang lebih banyak memfasilitasi pembayaran sehingga rasio modal yang dimiliki atau yang terdapat dalam BPRS memiliki prosentase kecil dibandingkan pembiayaan. BPRS dalam melakukan pembiayaan akan lebih meninjau DPK atau dana pihak ketiga dibandingkan CAR.

\section{Pengaruh ROA terhadap pembiayaan sektor manufaktur}

Hasil penelitian menunjukkan nilai prob 0.205 mengindikasikan bahwa ROA tidak memiliki hubungan signifikan karena melebihi tingkat signifikansi lebih dari 0.05 dan tidak berkaitan dengan pembiayaan pada BPRS. Tidak adanya pengaruh yang signifikan pada ROA dapat dimungkinkan rendahnya tingkat pengembalian pada asset yang dimiliki setelah dipotong pajak pada BPRS. Hasil ini tidak sejalan degan penelitian lain yang menghasilkan adanya pengaruh ROA terhadap pembiayaan.

\section{Pengaruh ROE terhadap pembiayaan sektor manufaktur}

Hasil penelitian ROE menunjukkan nilai 0.936 dimana hal ini menunjukkan ROE mengalami hubungan yang tidak signifikan karena melebihi nilai tingkat signifikansi 0.05 maka ROE tidak berhubungan terhadap pembiayaan pada sektor manufaktur. ROE juga tidak memiliki pengaruh pada BPRS karena mungkin BPRS merupakan lembaga keuangan yang menangani lalu lintas pembayaran.

\section{Pengaruh NPF terhadap pembiayaan sektor manufaktur}

Pada variabel NPF tidak memiliki hubungan yang signifikan sebesar 0.056 dimana melebihi tingkat signifikansi melebihi 0.05 dan berhubungan secara negatif pada pembiayaan sektor manufaktur. Variabel NPF tidak 
berpengaruh terhadap pembiayaan manufaktur dapat dikarenakan berapapun kredit dalam BPRS, kecukupan modal BPRS masih dapat digunakan untuk aktivitas pembiayaan lain. Semakin tinggi nilai rasio NPF maka semakin buruk pula kualitas pembiayaan atau kredit yang disalurkan.

\section{Pengaruh BOPO terhadap pembiayaan sektor manufaktur}

Hasil penelitian menunjukkan BOPO dimana variabel memiliki nilai prob 0.279 dan melebihi nilai signifikansi 0.05 sehingga BOPO tidak memiliki hubungan signifikan terhadap pembiayaan pada BPRS. Penelitian yang dilakukan (Nurafini et al., 2018) juga memberikan hasil tidak adanya pengaruh BOPO terhadap pembiayaan UKM di perbankan syariah.

\section{Pengaruh Dana Pihak Ketiga terhadap pembiayaan sektor manufaktur}

Pada Tabel. 1 menunjukkan bahwa dana pihak ketiga memiliki pengaruh pada pembiayaan pada sektor manufaktur sebesar 0.024 kurang dari tingkat signifikansi 0.05. Hal ini dikarenakan dana pihak ketiga merupakan dana yang berasal dari masyarakat dapat berupa giro iB, Tabungan iB dan deposito. Sehingga pembiayaan yang dilakukan besar kecilnya ditentukan oleh dana pihak ketiga. Hasil ini diperkuat dengan penelitian yang dilakukan oleh (Gampito, 2014) yang meneliti mengenai pengaruh dana pihak ketiga terhadap penyaluran dana perbankan syariah di Sumatera barat. Menggunakan variabel DPK yaitu giro, tabungan, deposito memiliki pengaruh yang signifikan terhadap penyaluran dana pembiayaan pada perbankan syariah di Sumatera barat. Penelitian yang dilakukan oleh (Amelia \& Hardini, 2017) mengenai variabel yang mempengaruhi penyaluran pembiayaan pada BPRS dimana variabel yang digunakan adalah dana pihak ketiga, rasio kecukupan modal, inflasi, nilai tukar dan tingkat bagi hasil mempengaruhi penyaluran pembiayaan.

\section{Pengaruh Akad Pembiayaan terhadap pembiayaan sektor manufaktur}

Hasil penelitian yang dilakukan menunjukkan hasil sebesar 0.0317 kurang dari tingkat signifikansi 0.05 maka variabel akad pembiayaan mempengaruhi sektor manufaktur. Pembiayaan merupakan salah satu aktivitas yang dijalankan oleh perbankan dalam bentuk menyalurkan dana kepada masyarakat. Menurut Undang-Undang perbankan no 10 tahun 1998 pembiayaan adalah penyediaan atau tagihan atau yang dapat dipersamakan dengan itu berdasarkan persetujuan atau kesepakatan antara bank dan pihak lain yang dibiayai untuk mengembalikan uang atau tagihan tersebut dalam waktu tertentu dengan imbalan atau bagi hasil. Pada Tabel.1 menjelaskan bahwa akad pada pembiayaan memiliki pengaruh pada pembiayaan pada sektor manufaktur di BPRS hal ini dikarenakan memberikan pembiayaan 
kepada sektor riil dapat dikatakan memberikan kehidupan bagi mereka untuk dapat melakukan kegiatan operasionalnya, menghasilkan produk dan dapat dimanfaatkan oleh masyarakat luas. Hasil ini diperkuat dengan penelitian yang dilakukan oleh (Muklis \& Fauziah, 2015) yang meneliti mengenai mudharabah, murabahah dan musyarakah pengaruhnya terhadap laba bersih BUS di Indonesia dimana menggunakan variabel pembiayaan mudharabah, murabahah dan musyarakah dengan variabel dependen adalah laba bersih. Hasil penelitian menunjukkan bahwa variabel pembiayaan secara simultan mempengaruhi laba bersih pada Bank Umum syariah.

\section{Pengaruh Inflasi terhadap pembiayaan sektor manufaktur}

Hasil penelitian dari inflasi sebesar 0.0000 kurang dari signifikansi 0.05 maka mempengaruhi secara signifikan terhadap manufaktur. Inflasi merupakan kecenderungan dari harga meningkat secara terus menerus. Inflasi dihitung menggunakan angka indeks sekelompok barang dan jasa. Pada Tabel.1 menjelaskan bahwa inflasi memiliki pengaruh pada pembiayaan sektor manufaktur di BPRS hal ini dikarenakan peningkatan inflasi dapat berarti peningkatan pula harga bahan baku yang digunakan untuk melakukan kegiatan produksi pada industri manufaktur. Hasil ini diperkuat dengan penelitian yang dilakukan oleh (Saekhu, 2016) mengenai pengaruh inflasi terhadap kinerja pembiayaan bank syariah, volume pasar uang antar bank syariah, dan posisi outstanding sertifikat wadiah bank Indonesia.

\section{Pengaruh Kurs atau nilai tukar terhadap pembiayaan manufaktur}

Hasil penelitian ini menunjukkan nilai probabilitas 0.033 kurang dari 0.05 sehingga hasil probabilitas berpengaruh secara signifikan terhadap manufaktur. Pada Tabel. 1 menjelaskan bahwa dana pihak ketiga memiliki pengaruh pada pembiayaan sektor manufaktur di BPRS hal ini dikarenakan kurs atau nilai tukar memiliki andil dalam pembiayaan pada sektor BPRS dikarenakan kemungkinan adanya barang yang diimpor dari luar negeri sehingga mereka menggunakan mata uang lain dalam melakukan transaksi perekonomian. Hasil ini diperkuat dengan penelitian yang dilakukan oleh (Rifai et al., 2017) dimana pada penelitian ini menganalisa mengenai pengaruh kurs rupiah, laju inflasi, jumlah uang beredar dan pertumbuhan ekspor terhadap total pembiayaan perbankan syariah dengan Dana Pihak Ketiga sebagai variabel moderating. Hasil penelitian menunjukkan adanya hubungan simultan nilai tukar, inflasi, jumlah uang beredar dan pertumbuhan ekspor mempengaruhi total pembiayaan. 


\section{KESIMPULAN}

Penelitian mempelajari mengenai faktor-faktor yang mempengaruhi pembiayaan sektor ekonomi riil manufaktur di Indonesia pada Bank Pembiayaan Rakyat Syariah. Penelitian ini mengambil data BPRS di Indonesia mulai tahun 2014 hingga 2018. Variabel yang digunakan dalam penelitian ini adalah sektor riil atau manufaktur sebagai variabel dependen, CAR, ROA, ROE, NPF, BOPO, DPK, Akad Pembiayaan, inflasi dan kurs sebagai variabel independen. Uji yang digunakan adalah regresi berganda atau multivariate dimana didapatkan hasil bahwa CAR, ROA, ROE, NPF, BOPO, DPK, Akad Pembiayaan, Inflasi dan kurs secara simultan mempengaruhi sektor manufaktur. Sedangkan uji pada tiap variabel menghasilkan bahwa CAR, ROA, ROE, NPF, BOPO tidak berpengaruh signifikan kepada manufaktur. Dana Pihak Ketiga, Akad Pembiayaan, Inflasi dan Kurs berpengaruh signifikan terhadap manufaktur.

Penelitian ini memiliki implikasi bagi para wirausahawan, bank pembiayaan syariah dan pembuat kebijakan. Bank Pembiayaan Rakyat Syariah dapat memberikan pembiayaan yang lebih baik lagi bagi sektor manufaktur atau sektor ekonomi lain agar makin meningkatkan pertumbuhan ekonomi di Indonesia yang mampu bertahan dalam gejolak krisis apapun. Studi ini memiliki keterbatasan dimana hanya meneliti mengenai pembiayaan manufaktur yang dilakukan oleh BPRS. Untuk penelitian selanjutnya dapat menambah sektor ekonomi lain serta menggunakan variabel lain yang lebih merepresentasikan pembiayaan pada sektor riil di Indonesia.

\section{DAFTAR PUSTAKA}

Abas, S. (2017). The Role Of Sharia Banking In Strengthening The Micro, Small, And Medium Enterprises In North Maluku, Indonesia. International Journal of Scientific \& Technology Research, 6(10).

Agza, Y., \& Darwanto, D. (2017). Pengaruh Pembiayaan Murabahah, Musyarakah, Dan Biaya Transaksi Terhadap Profitabilitas Bank Pembiayaan Rakyat Syariah. Iqtishadia: Jurnal Kajian Ekonomi Dan Bisnis Islam STAIN Kudus, 10(1), 228-248.

Al Arif, M. N. R. (2012). Lembaga Keuangan Syariah: Suatu Kajiajn Teoretis dan Praktis. Pustaka Setia.

Amelia, E., \& Hardini, E. F. (2017). Determinant of Mudharabah Financing: A Study at Indonesian Islamic Rural Banking. Etikonomi, 16(1), 43-52. https://doi.org/10.15408/etk.v16i1.4638

Badan Pusat Statistik. (2019). Pertumbuhan industri manufaktur. https://www.bps.go.id/website/images/BRS-IBS-NOV-2018-ind.png

Diallo. (2018). Bank efficiency and industry growth during financial crises. Economic Modelling, 68, 168-177.

Fithria, A., \& Sholihin, M. (2018). Analyzing the Performance of Indonesian 
Islamic Rural Banks: Does Bank Size Matter? International Journal of Islamic Economics and Finance Research, 1(2), 54-68.

Gampito. (2014). Pengaruh Dana Pihak Ketiga Terhadap Penyaluran Dana Perbankan Syariah Di Sumatera Barat. JURIS, 13(1).

Hosen, M. N., \& Muhari, S. (2019). Non-performing financing of Islamic rural bank industry in Indonesia. Banks and Bank Systems, 14(1), 20-28. https://doi.org/10.21511/bbs.14(1).2019.03

Kompas. (2016). Indonesia Masuk 10 Besar Manufaktur. Kementrian Perindustrian.

https://kemenperin.go.id/artikel/15069/Indonesia-Masuk-10-BesarManufaktur

Kusmayadi, D. (2018). Analysis of Effect of Capital Adequacy Ratio, Loan to Deposit Ratio, Non Performing Loan, Bopo, and Size on Return on Assets in Rural Banks at Indonesia. Saudi Journal of Business and Management Studies (SJBMS), 3(7), 786-795.

https://doi.org/10.21276/sjbms.2018.3.7.4

Masudah. (2017). Determinan Volume Pembiayaan Bank Umum Syariah Indonesia. Ikonomika: Journal of Islamic Economics and Business, 2(1), 53-62. https://doi.org/10.24042/febi.v2i1.943

Muhaemin, A., \& WIliasih, R. (2016). Analisis Faktor-Faktor Yang Memengaruhi Profitabilitas Bank Pembiayaan Rakyat Syariah Di Indonesia. Jurnal Nisbah, 2 (1), 181-207.

Muklis, \& Fauziah, S. (2015). Mudharabah, Murabahah, dan Musyarakah Pengaruhnya Terhadap Laba Bersih BUS di Indonesia. Jurnal Islaminomic, 06 (2).

Nurafini, F., Sukmana, R., \& Herianingrum, S. (2018). The External and Internal Factors on Small and Medium Enterprise ( SMEs ) Financing in Islamic. Advances in Social Science, Education and Humanities Research (ASSEHR), 98 (Icpsuas 2017), 122-126.

Permatasari, Devi; Yulianto, A. R. (2018). Analisis Kinerja Keuangan: Kemampuan Bank Syariah. Jurnal Akutansi Indonesia, 7 (1), 69-79.

Rafay, A., \& Farid, S. (2017). Dynamic relationship between islamic banking system and real economic activity: Evidence from Pakistan. Journal of King Abdulaziz University, Islamic Economics, 30 (2), 97-116. https://doi.org/10.4197/Islec.30-2.10

Rahmat Dahlan. (2014). Pengaruh Tingkat Bonus Sertifikat Bank Indonesia Syariah Dan Tingkat Inflasi Terhadap Pembiayaan Bank Syariah Di Indonesia. Rahmat Dahlan Universitas Muhammadiyah Prof. Dr. Hamka. Jurnal Etikonomi, 13(2), 104-117.

Rifai, S. A., Susanti, H., \& Setyaningrum, A. (2017). Analisis Pengaruh Kurs Rupiah, Laju Inflasi, Jumlah Uang Beredar dan Pertumbuhan Ekspor terhadap Total Pembiayaan Perbankan Syariah dengan Dana Pihak Ketiga sebagai Variabel Moderating. MUQTASID Jurnal Ekonomi Dan Perbankan Syariah, 8 (1), 18.

https://doi.org/10.18326/muqtasid.v8i1.18-39

Saekhu, S. (2016). Pengaruh Inflasi Terhadap Kinerja Pembiayaan Bank Syariah, Volume Pasar Uang Antar Bank Syariah, Dan Posisi 
Outstanding Sertifikat Wadiah Bank Indonesia. Economica: Jurnal Ekonomi Islam, 6 https://doi.org/10.21580/economica.2015.6.1.788

(1), 103.

Suhel, S., Asngari, I., Mardalena, M., \& Andaiyani, S. (2018). The Economic Scale of Small-Medium Enterprises Financing in Sharia Banking. International Journal of Economics and Financial Issues, 8(3), 112-117.

Undang-Undang No. 7 Tahun 1992 mengenai Bank berdasarkan prinsip bagi hasil

Undang-Undang No. 10 Tahun 1998

Undang-Undang No. 21 Tahun 2008 mengenai perbankan syariah

Viverita, L. A. ., Bustaman, Y., \& Riyanti, R. . (2015). Foreign bank entry and credit allocation to SMEs: evidence from ASEAN countries. ProcediaSocial and Behavioral Sciences, 211, 1049-1056.

Wiyono, A. A., \& Mulatsih, S. (2017). Analisis Faktor Eksternal Dan Performance Indikator Bprs Indonesia Terhadap Pembiayaan Sektor Perdagangan, Hotel Dan Restoran. Jurnal Ekonomi Dan Kebijakan Pembangunan, 6 (2), 74-89.

Yusof, Rosylin Mohd; Bahlous, M. (2013). Islamic banking and economic growth A panel cointegration analysis. Journal of Islamic Accounting and Business Research, 4, 151-172.

https://doi.org/10.1108/JIABR-07-2012-0044

https://www.ojk.go.id/

https://www.kompas.com/

https://www.bi.go.id/ 